\title{
Apocynaceae s.l. na Reserva Biológica da Represa do Grama, Descoberto, Minas Gerais, Brasil
}

\author{
Carolina Nazareth Matozinhos ${ }^{1}$ \& Tatiana Ungaretti Paleo Konno ${ }^{2}$
}

\begin{abstract}
RESUMO
(Apocynaceae s.l. na Reserva Biológica da Represa do Grama, Descoberto, Minas Gerais, Brasil) A Reserva Biológica da Represa do Grama está localizada no município de Descoberto, Zona da Mata do estado de Minas Gerais. A Reserva abrange uma área de 263,8 hectares com a predominância de florestas estacionais semideciduais baixo-montanas. Apocynaceae s.l. está representada na área por 12 espécies, distribuídas nos gêneros Asclepias, Aspidosperma, Condylocarpon, Ditassa, Forsteronia, Himatanthus, Macroditassa, Matelea, Rauvolfia, Secondatia e Tabernaemontana. Neste trabalho, são fornecidos chaves de identificação, descrições, ilustrações, distribuição geográfica e comentários para cada espécie.
\end{abstract}

Palavras-chave: Asclepiadaceae, flora, Zona da Mata, floresta estacional.

\section{Abstract}

(Apocynaceae s.l. in the "Reserva Biológica da Represa do Grama", Descoberto, Minas Gerais, Brazil) The "Reserva Biológica da Represa do Grama", located in the Municipality of Descoberto, Minas Gerais State, has 263,8 hectares, mostly covered by seasonal, semideciduous forest. Apocynaceae s.l. is represented in the area by 12 species and 11 genera (Asclepias, Aspidosperma, Condylocarpon, Ditassa, Forsteronia, Himatanthus, Macroditassa, Matelea, Rauvolfia, Secondatia e Tabernaemontana). Keys for genera and species, descriptions, illustrations, distribution and comments for each species are provided.

Key words: Asclepiadaceae, flora, Zona da Mata, semidecidous forest.

\section{INTRODUÇÃ̃o}

A região da Zona da Mata do estado de Minas Gerais é constituída, em grande parte, por Florestas Estacionais Semideciduais Montanas e Submontanas (Projeto RADAMBRASIL 1983). Essas florestas encontram-se extremamente fragmentadas, devido a diversos tipos de perturbações, como fogo, pecuária, retirada seletiva de madeira e a crescente expansão das áreas urbanas (Oliveira-Filho et al. 1994; Meira-Neto et al. 1997).

Estudos a cerca dos fragmentos florestais em Minas Gerais, em especial na Zona da Mata, são esparsos e estão, em sua grande maioria, voltados para aspectos fitofisionômicos e estruturais (vide Meira-Neto et al. 1997; Lopes et al. 2002; Maragon et al. 2003; Silva et al. 2003; Ribas et al. 2003). Apesar do esforço empregado na elaboração de listagens florísticas, as abordagens taxonômicas para a região são ainda esparsas (e.g. Braz et al. 2002; Pereira et al. 2006).
A Reserva Biológica da Represa do Grama (RBRG) destaca-se dentre esses fragmentos por localizar-se em uma área de Importância Biológica Muito Alta e por estar incluída no Corredor Sudeste da Mata Atlântica, que congrega outros fragmentos importantes da Zona da Mata de Minas Gerais (Drummond et al. 2005). Desta forma, apresentamos um tratamento taxonômico para as espécies de Apocynaceae s.l. ocorrentes na área, dando continuidade aos estudos na RBRG (vide Pivari \& Forzza 2004; Menini Neto et al. 2004; Assis et al. 2005; Almeida et al. 2005; Lobão et al. 2006). Objetiva-se com isso ampliar os dados sobre a vegetação de Minas Gerais e contribuir para o conhecimento taxonômico e biogeográfico desta família botânica.

\section{Material e Métodos}

A Reserva Biológica da Represa do Grama (RBRG) está localizada na mesorregião da Zona da Mata de Minas Gerais, no

Artigo recebido em 06/2007. Aceito para publicação em 01/2008.

${ }^{1}$ Acadêmica do Curso de Ciências Biológicas, Universidade Federal de Juiz de Fora, Instituto de Ciências Biológicas, Herbário CESJ, Campus Universitário, Martelos, 36036-330, Juiz de Fora, MG, Brasil. cnmatozinhos@ gmail.com ${ }^{2}$ Núcleo em Ecologia e Desenvolvimento Sócio-Ambiental de Macaé - NUPEM, Universidade Federal do Rio de Janeiro, Rua Rotary Club s/n, São José do Barreto, C.P. 119331, 27910-970, Macaé, RJ, Brasil. tkonno@uol.com.br 
município de Descoberto $\left(21^{\circ} 25^{\prime} \mathrm{S}\right.$ $42^{\circ} 56^{\prime} \mathrm{W}$ ), cerca de $100 \mathrm{~km}$ ao NE de Juiz de Fora, e foi a primeira Reserva Biológica criada no estado. A RBRG abrange uma área de 263,8ha. de Floresta Estacional Semidecidual Montana, abrigando dois córregos que abastecem parcialmente os municípios de Descoberto e São João Nepomuceno (Pivari \& Forzza 2004; Menini Neto et al. 2004).

Foram analisadas as coleções depositadas no Herbário CESJ, provenientes de coletas mensais realizadas entre 1999 e 2000, e material adicional de procedências distintas a partir das coleções depositadas nos herbários BHCB, CESJ e RB. As descrições e ilustrações das espécies foram baseadas nos materiais coletados na RBRG. Aspectos morfológicos florais foram uniformizados para Apocynaceae s.l., aplicando-se o termo clavúncula para designar a cabeça do estilete em Apocynaceae s.str. e cabeça do ginostégio em Asclepiadoideae (Konno 2005).

\section{Tratamento Taxonômico}

Apocynaceae reúne cerca de 450 gêneros e 4.950 espécies com distribuição pantropical. No Brasil, ocorrem em ambientes campestres e florestais com cerca de 60 gêneros e 750 espécies (Giulietti et al. 2005), representadas em três subfamílias: Asclepiadoideae,
Rauvolfioidae e Apocynoideae (Endress \& Bruyns 2000).

São árvores, arbustos, lianas, trepadeiras ou ervas, latescentes. Folhas simples, alternas, opostas ou verticiladas, geralmente com coléteres nas axilas e/ou na base da lâmina foliar. Flores solitárias ou em cimeiras, hermafroditas, actinomorfas, pentâmeras. Corola geralmente contorta, campanulada, infundibiliforme ou hipocrateriforme, de colorido variado. Estames 5, epipétalos, anteras introrsas, por vezes adnatas à clavúncula (porção dilatada do estilete onde encontra-se a região estigmática), formando um ginostégio em Asclepiadoideae. Ovário súpero (semi-ínfero em Himatanthus), bicarpelar, geralmente apocárpico, glabro ou piloso; nectários ou discos nectaríferos geralmente presentes. Folículos secos ou carnosos, por vezes moniliformes, lomentos, drupas e bagas, sementes nuas, aladas, plumosas, por vezes ariladas.

$\mathrm{Na}$ RBRG, as três subfamílias de Apocynaceae ocorrentes no Brasil estão representadas por 11 gêneros: Aspidosperma, Condylocarpon, Tabernaemontana, Himatanthus e Rauvolfia são gêneros da subfamília Rauvolfioideae; Forsteronia e Secondatia pertencem às Apocynoideae; os demais, Asclepias, Ditassa, Macroditassa e Matelea fazem parte das Asclepiadoideae.

\section{Chave de identificação para as espécies de Apocynaceae s.l. da Reserva do Grama}

1. Prefloração da corola sinistrorsa; frutos com sementes sem coma. I. Subfamília Rauvolfioideae

2. Lianas; domáceas presentes na lâmina foliar; frutos indeiscentes, moniliformes com mericarpos articulados 2. Condylocarpon isthimicum

2'. Árvores ou arvoretas; domáceas ausentes na lâmina foliar; frutos foliculares não articulados ou drupáceos.

3. Inflorescências com brácteas foliáceas, conspícuas; flores com sépalas desiguais; tubo da corola 15-20 mm compr.

3. Himatanthus lancifolius

3'. Inflorescências com brácteas escamiformes, inconspícuas; flores com sépalas iguais; tubo da corola 1-9 mm compr.

4. Coléteres ausentes nas sépalas; estames inseridos próximo a fauce da corola, acima da clavúncula; disco nectarífero anular.

5. Folhas verticiladas; coléteres presentes na região nodal; inflorescência terminal com 2-3 paracládios pleioasiais; clavúncula com tricomas na base 4. Rauvolfia mattfeldiana 
5'. Folhas alternas; coléteres ausentes na região nodal; inflorescência axilar, cimosa; clavúncula sem tricomas na base 1. Aspidosperma spruceanum

4'. Coléteres presentes nas sépalas; estames inseridos no terço inferior do tubo da corola, abaixo da clavúncula; disco nectarífero ausente.

6. Botões florais de ápice largo ovóide; sépalas ovadas, eretas; lobos da corola 9-15 mm compr.

5. Tabernaemontana laeta

6'. Botões florais de ápice elipsóide; sépalas lanceoladas, curvadas a patentes; lobos da corola 5-7 mm compr.

6. Tabernaemontana hystrix

1'. Prefloração da corola dextrorsa ou valvar; frutos com sementes comosas.

7. Pólen liberado individualmente (mônades ou tétrades). (II. Subfamília Apocynoideae).

8. Flores com corola sub-rotácea; estames parcialmente exsertos, filetes inseridos no tubo da corola, parcialmente livres com apêndice caloso; folículo moniliforme .....

7. Forsteronia refracta

8'. Flores com corola hipocrateriforme; estames inclusos; filetes totalmente adnatos ao tubo da corola, sem apêndice caloso no ápice; folículo fusiforme

8. Secondatia densiflora

7'. Pólen agrupado em polínias (III. Subfamília Asclepiadoideae).

9. Erva ereta; flores com corola vermelha; sépalas e lobos da corola reflexos

9. Asclepias curassavica

9'. Trepadeira; flores com corola alva a esverdeada; sépalas e lobos da corola patentes ou eretos.

10. Corola com calosidades verrucoso-pilosas entre os lobos na fauce; corona com segmentos bicornados no ápice; polínias horizontais com caudículas articuladas

12. Matelea capillacea

10'. Corola sem calosidades na fauce; corona com segmentos inteiros; polínias pendentes com caudículas não articuladas.

11. Folhas tomentosas; inflorescência subaxilar, alterna; corola campanulada, pubérula; segmentos externos da corona planos, mais baixos que o ginostégio

10. Ditassa tomentosa

11'. Folhas glabras; inflorescência axilar, oposta; corola rotácea, internamente barbelada; segmentos externos da corona cuculados na base, mais altos que o ginostégio 11. Macroditassa lagoensis var. cucullata

\section{Subfamília Rauvolfioideae}

Folhas alternas, opostas ou verticiladas. Corola com prefloração sinistrorsa; anteras livres da clavúncula. Pólen em mônades ou tédrades liberados individualmente. Sementes sem coma, aladas, ariladas, ou nuas.

1. Aspidosperma spruceanum Benth. ex Müll. Arg., Fl. bras. 6(1): 52. 1860.

Fig. 1, d-e

Árvore 10-18 m alt., ramos lisos, acinzentados, lenticelas ausentes, pubescentes; coléteres ausentes na região nodal. Folhas alternas, iguais entre si; pecíolo 13-28 mm compr., glabro; lâmina foliar 5,2-9 × 2,8-3,2 cm, oblongo-lanceolada, ápice acuminado, margem inteira, base aguda, subcoriácea, face abaxial pulverulenta e adaxial glabra, lustrosa. Inflorescência axilar, cimosa, multiflora; pedúnculo 5,6-6 $\mathrm{cm}$ compr.; brácteas escamiformes, inconspícuas. Flores amarelas a laranja; pedicelo ca. 0,7 $\mathrm{mm}$ compr., tomentoso; sépalas ca. $3 \times 1 \mathrm{~mm}$ compr., iguais entre si, eretas, ovadas, tomentosas, coléteres ausentes; corola hipocrateriforme, lobos ca. 2 $\times 1 \mathrm{~mm}$, lineares a lanceolados; tubo 3-4 mm compr., ligeiramente dilatado na base, internamente piloso; estames inclusos, inseridos 
próximo a fauce, acima da clavúncula, filetes fundidos ao tubo; anteras ca. $5 \mathrm{~mm}$, ovadas. Ovário oblongo-ovóide, glabro; disco nectarífero anular; estilete ca. 0,4 mm compr., cilíndrico; clavúncula clavada com apêndice bífido, glabra. Folículos castanho-cinzentos, 7,5-8,5 × 4,1-5 cm, piriformes, tomentosos; sementes ca. $6 \times 4,8 \mathrm{~cm}$, orbiculares com alas alvas.

Material examinado: IX.2002, fr., R.C. Forzza et al. 2215 (CESJ).

Material adicional examinado: BRASIL, MINAS GERAIS: Belo Horizonte, III.2002, fl., J.R. Stehmanm et al. 3026 (BHCB).

Aspidosperma spruceanum é facilmente reconhecível pelo grande porte, látex vermelho e folhas coriáceas (Marcondes-Ferreira 1988). A espécie tem ampla distribuição em formações de mata no território brasileiro, com seu limite sul sendo a Serra da Mantiqueira. É frequiente nas matas de Minas Gerais (OliveiraFilho 2006).

\section{Condylocarpon isthmicum (Vell.) A.DC.,} Prodr. 8: 381. 1844.

Fig. 1, f-i

Liana lenhosa, ramos lisos, os jovens castanhos, os velhos acinzentados, esparsamente lenticelados, tomentulosos; coléteres presentes próximo a base do pecíolo. Folhas verticiladas, 3 por nó, iguais entre si; pecíolo 0,7-1,6 mm compr., glabro; lâmina foliar 7-9,5 × 3,4-3,7 cm elíptica a elíptico-ovada, ápice agudo a caudado, margem inteira, base atenuada, cartácea, glabra, domáceas presentes na face abaxial. Inflorescência axilar, cimosa, multiflora; pedúnculo ca. $4 \mathrm{~cm}$ compr.; brácteas inconspícuas; botões florais globóides, ca. 4 mm compr.. Flores alvoamareladas; pedicelo 1-4 mm compr., glabro; sépalas ca. $0,1 \mathrm{~mm} \times 0,2 \mathrm{~mm}$, iguais entre si, eretas, ovadas, glabras, coléteres ausentes; corola infundibuliforme, lobos ca. $4 \times 1,5 \mathrm{~mm}$, longamente caudados; tubo ca. $1 \mathrm{~mm}$ compr., alargado na base, internamente piloso; estames inclusos, inseridos na porção mediana do tubo, acima da clavúncula, filetes fundidos ao tubo; anteras ca. $2 \mathrm{~mm}$ compr., ovadas. Ovário piriforme, glabro, disco nectarífero ausente; estilete ca. 0,2 mm compr.; clavúncula subglobosa a globosa, sem apêndices, séssil. Folículo moniliforme, mericarpos articulados, verdes a castanhos, ca. $11 \times 14,5 \mathrm{~cm}$, glabros; sementes ca. $1 \mathrm{~cm}$ compr., fusiformes.

Material examinado: XI.2000, fl. R.C. Forzza et al. 1707 (CESJ); III.2004, fr., R.C. Forzza et al. 2944 (RB). Condylocarpon isthmicum é reconhecível pelos frutos articulados e lâminas foliares com domáceas. Espécie heliófila de ampla distribuição (Fallen 1983), ocorrendo principalmente em mata ciliares ou áreas perturbadas. Na RBRG, é encontrada em abundância no interior da mata.

3. Himatanthus lancifolius (Müll. Arg.) Woodson, Ann. Missouri Bot. Gard. 25: 193. 1938.

Fig. 1, a-c

Arvoreta, 3-7 $\mathrm{m}$ alt., ramos suberosos, avermelhados, não lenticelados, glabros; coléteres ausentes na região nodal. Folhas alternas, iguais entre si; pecíolo 2,1-2,6 cm compr., glabro; lâmina foliar 11,5-22 × 3-5,5 $\mathrm{cm}$, oblongo-lanceolada, ápice acuminado curto caudado, margem inteira, base atenuada, subcoriácea, glabra. Inflorescência terminal, cimosa, multiflora; pedúnculo 3-4 cm compr.; brácteas foliáceas, petalóides, com 2 flores geminadas e 1 botão elipsóide. Flores brancas; pedicelo 4-9 mm compr., glabro; sépalas 0,5$2 \mathrm{~mm}$ compr., desiguais, 2 ou 3 pequenas, 1 ou 2 maiores, eretas, as menores triangulares e as maiores lanceoladas, glabras, coléteres ausentes; corola hipocrateriforme, lobos 17$21 \times$ ca. $6 \mathrm{~mm}$, oblongo elípticos; tubo 1,5-2 cm compr., estreito, internamente piloso; estames inclusos, inseridos na base do tubo, acima da clavúncula; filetes fundidos ao tubo; anteras ca. $3 \mathrm{~mm}$ compr., ovadas. Ovário oblongo, glabro; disco nectarífero ausente; estilete ca. $3 \mathrm{~mm}$ compr., colunar; clavúncula sem tricomas, com apêndice bífido, curto. Frutos não observados.

Material examinado: XI 2001, fl., R. Castro \& D.S. Pifano 691(CESJ); II 2001, fl., L.Meireles et al. s.n. (CESJ 34464).

Himatanthus lancifolius é distinguível por seu caule rugoso e inflorescência articulada 

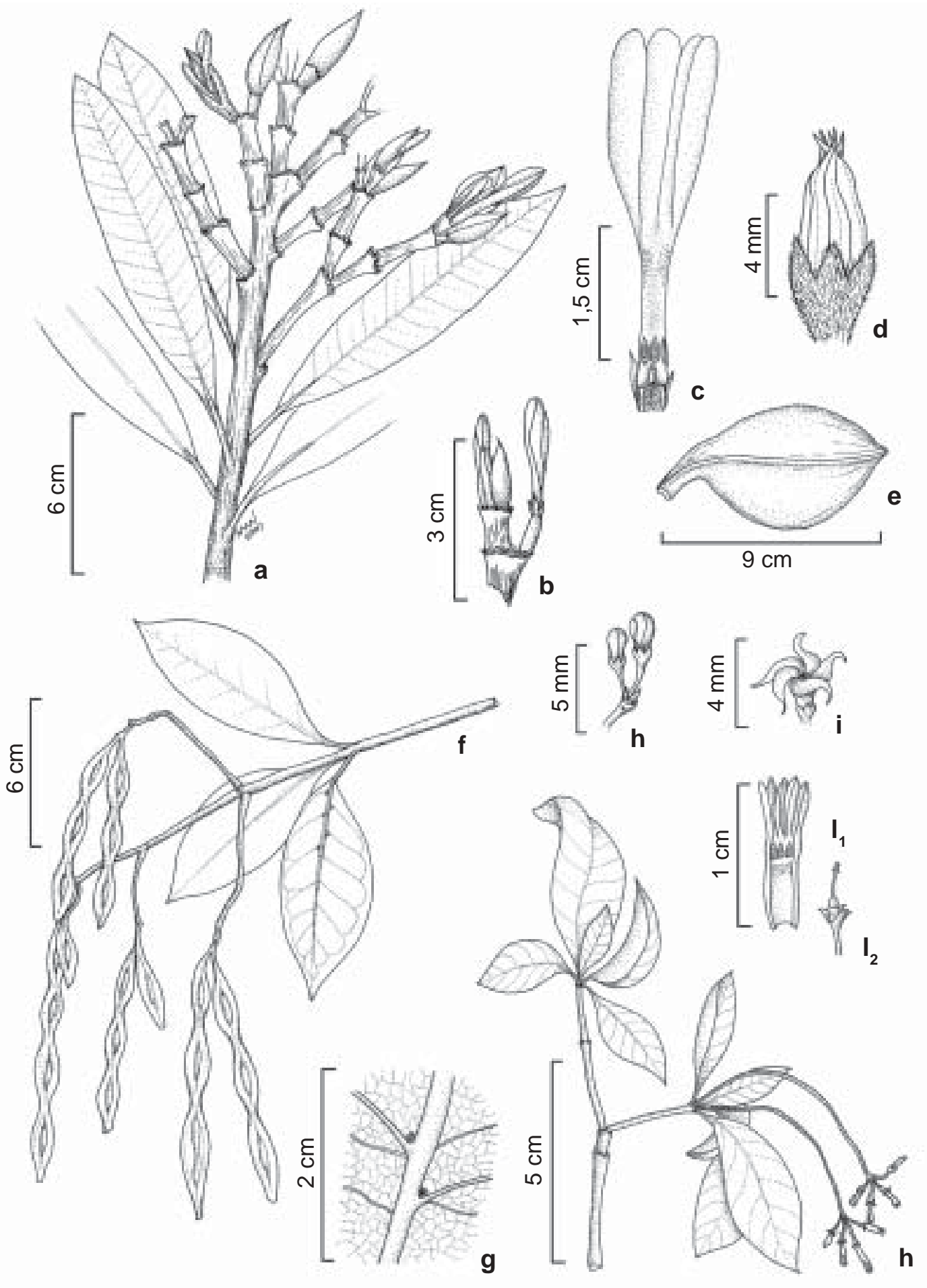

Figura 1 - a-c. Himatanthus lancifolius - a. ramo com inflorescência, b. detalhe do botão e bráctea floral, c. detalhe da flor com uma pétala removida. d-e. Aspidosperma spruceanum - d. flor, e. fruto. f-i. Condylocarpon isthmicum - f. ramo com frutos; g. detalhe das domácias na face abaxial da lâmina foliar; h. botões florais; i. flor. j-1. Rauvolfia mattfeldiana-j. ramo com inflorescência; $1_{1}$. corola aberta mostrando os estames; $1_{2}$. detalhe do gineceu. (a-c Castro 691; d-e Forzza 2215; f-i Forzza 1707; j-1 Castro 744). 
com muitos coléteres. Distribui-se pelos estados do Rio de Janeiro, Minas Gerais, Espírito Santo e Bahia. É morfologicamente próximo de $H$. phagedaenicus (Mart.) Woods, porém este possui folhas oblanceolares mais largas e também flores maiores (Plumel 1991). Spina (2004) considera H. lancifolius um sinônimo de $H$. bracteatus (A.DC.) Woods. Contudo, por ser um posicionamento taxonômico ainda inédito, não será aqui adotado. De acordo com Oliveira-Filho (2006), H. lancifolius é rara para a região de Minas Gerais. A espécie foi coletada na RBRG em borda de mata ou mata ciliar.

4. Rauvolfia mattfeldiana Markgr., Repert. Spec. Nov. Regni Veg. 20: 120. 1924.

Fig. 1 j-1

Arbusto ca. $2 \mathrm{~m}$ alt., ramos levemente rugosos, os jovens castanhos e os velhos acinzentados, lenticelados, glabros; coléteres presentes na região nodal. Folhas verticiladas, 4-5 por nó, anisófilas; pecíolo 4-7 mm compr., glabro; lâmina foliar 2-7,8 ×0,8-1,3 cm, elíptica a oval-elíptica, ápice agudo a caudado, margem levemente revoluta, base aguda, membranácea a cartácea, glabra, nervura primária proeminente. Inflorescência terminal, com 2-3 paracládios fasciculados, pleiocasiais, 2-5 flores; pedúnculo 2,5-3 cm compr.; brácteas escamiformes inconspícuas. Flores brancas com máculas vermelhas nos lobos; pedicelo 0,8-1 cm compr., glabro; sépalas 1-2 $\times$ ca. $1 \mathrm{~mm}$, iguais entre si, eretas, triangulares, glabras, coléteres ausentes; corola hipocrateriforme, lobos ca. 3 x 1,2 mm, oblíquos-oblongos; tubo ca. $6 \mathrm{~mm}$ compr., alargado no terço superior, internamente piloso; estames inclusos, inseridos próximo a fauce, acima da clavúncula, filetes fundidos ao tubo; anteras 0,7-1 mm compr., ovadas de ápice apiculado. Ovário orbicular, glabro; disco nectarífero anular; estilete 2-3,2 mm compr., cilíndrico; clavúncula cilíndrica, alargando na base, com coroa de tricomas. Frutos não observados. Material examinado: XII. 2001, fl., R. Castro et al. 744 (CESJ).
Rauvolfia mattfeldiana distingue-se das demais espécies da RBRG pelos catáfilos na região nodal e pelos paracládios fasciculados. As flores não ultrapassam $1 \mathrm{~cm}$ compr., sendo alvas com máculas vermelhas nos lobos.

Segundo Koch (2002), esta espécie é endêmica do Brasil, sendo sua localidade-tipo em ambientes secos de caatinga ou carrascos no estado da Bahia, ocorrendo também em vegetação de restinga no sul da Bahia e Espírito Santo. Este é o primeiro registro desta espécie para o estado de Minas Gerais e para formações de florestas estacionais, ampliando a distribuição geográfica e ecológica do táxon (I.Koch, comun. pess.).

5. Tabernaemontana hystrix Steud., Nomencl. Bot., ed. 2, 2: 658. 1841.

Fig. 2 a-b

Arvoretas 1,5-4 m alt., ramos rugosos, acinzentados, raro lenticelados, glabros; coléteres presentes na região nodal. Folhas opostas, anisófilas; pecíolo 0,5-1 mm compr., glabro; lâmina foliar 4,7-10 × 1,6-3,2 cm, estrito- elíptica a elíptica, ápice acuminado a curto caudado, margem inteira, base cuneada, cartácea a subcoriácea, glabra. Inflorescência axilar, cimosa, multiflora; pedúnculo 1,5-2,5 cm compr.; brácteas escamiformes, inconspícuas, botões florais de ápice elipsóide, 5-7 mm comp., menor ou igual ao tubo. Flores brancas a laranja; pedicelo 1-1,1 cm compr., glabro; sépalas ca. 4,3 mm compr., iguais entre si, curvas a patentes, lanceoladas, glabras, coléteres presentes; corola hipocrateriforme, lobos 5-7 × 2-3 mm, dolabriformes; tubo 79 mm compr., cilíndrico alargado na base, internamente piloso; estames inclusos, inseridos no terço inferior do tubo, abaixo da clavúncula, filetes fundidos ao tubo; anteras ca. $4 \mathrm{~mm}$ compr., sagitadas. Ovário ovóide, glabro; disco nectarífero ausente; estilete cilíndrico, ca. $2 \mathrm{~mm}$ compr.; clavúncula cilíndrica com 5 projeções basais, 5 projeções globosas no ápice e 2 apêndices apicais. Frutos não observados.

Material examinado: XI.2000, fl., R. C. Forzza et al. 1732 (CESJ); XI.2001, fl., R. Castro et al 690 (CESJ); 
XII.2001, fl., D. S. Pifano et al. 210 (CESJ); I.2001, fl., R. Castro et al. 766 (CESJ).

Tabernaemontana hystrix possui folhas mais cartáceas a subcoriáceas e flores com tubo mais longo que o ápice do botão floral, além de lobos menores quando comparada a T. laeta. Ocorre no sudeste do Brasil, sendo considerada raríssima na região de Minas Gerais (Oliveira-Filho 2006). Tabernaemontana hystrix é muito confundida com T. catharinensis. (Koch \& Kinoshita 1999). De acordo com Leeuwenberg (1994), as proporções entre os comprimentos do cálice, tubo da corola e lobos sustentam a diferenciação entre estas duas espécies. No entanto, a utilização destes caracteres dificulta uma identificação precisa, possivelmente decorrente da variação encontrada em fases ontogênicas distintas. Por ausência de outras características que sustentem este delineamento, julga-se necessário uma nova avaliação para estas duas espécies (I. Koch, comun. pess.)

6. Tabernaemontana laeta Mart. Flora 20, Beibl. 2: 98. 1837.

Fig. $2 \mathrm{c}-\mathrm{d}$

Arvoretas ou árvores 3-12 m alt., ramos rugosos, acinzentados a castanhos, lenticelados, glabros; coléteres presentes na região nodal. Folhas opostas, congestas no ápice dos ramos, anisófilas; pecíolo 0,5-1,7 mm compr., glabro; lâmina foliar 6-15 ×3,5-5,6 cm, oblanceolada a largo elíptica, ápice raramente retuso, acuminado a caudado, margem inteira, base cuneada oblíqua a atenuada, cartácea, glabra. Inflorescência axilar, cimosa, multiflora; pedúnculo 1,3-3,5 cm compr.; brácteas inconspícuas; botões florais ápice largo ovóide, ca. $8 \mathrm{~mm}$ compr., igual ao tubo. Flores brancas; pedicelo 9-16 mm compr., glabro; sépalas ca. $3 \times 1,8 \mathrm{~mm}$, iguais entre si, eretas, ovadas, glabras, coléteres presentes; corola hipocrateriforme; lobos 9-15×5-7 mm, dolabriformes; tubo ca. $8 \mathrm{~mm}$ compr., cilíndrico alargado na base, internamente piloso; estames inclusos, inseridos no terço inferior do tubo, abaixo da clavúncula; filetes fundidos ao tubo; anteras ca. $4 \mathrm{~mm}$ compr., sagitadas. Ovário ovóide, glabro; disco nectarífero ausente; estilete cilíndrico, 1,5-2 mm compr.; clavúncula com projeções na base e 2 apêndices apicais. Folículos verdes a castanhos, 3,1-3,7 × 2-2,8 cm, reniformes, muricados; sementes ca. $10 \times 4,5 \mathrm{~mm}$, elípticas, com arilo laranja.

Material examinado: X.2000, fl., L. Meirelles et al. s.n. (CESJ 31441); VI.2001, fl. e fr., R. Castro et al. 473 (CESJ); X.2001, fl., R. C. Forzza et al. 1896 (CESJ); XI.2001, fl., D. S. Pifano et al. 198 (CESJ).

Tabernaemontana laeta possui flores com lobos mais largos e folhas membranáceas. Ocorre por todo o sudeste do Brasil, principalmente em matas semideciduas. É considerada rara em Minas Gerais (Oliveira-Filho 2006). Na RBRG, é encontrada nas bordas de mata e em clareiras. Os aspectos fenológicos e ecológicos desta espécie são muito semelhantes aos da espécie $T$. hystrix que também ocorre na RBRG.

\section{Subfamília Apocynoideae}

Folhas opostas. Corola com prefloração dextrorsa; anteras adnatas a clavúncula; pólen em mônades ou tédrades liberados individualmente. Sementes comosas.

7. Forsteronia refracta Müll. Arg., Fl. bras. 6(1): 97. 1860.

Fig. 2 e-f

Liana, ramos rugosos, castanhos, lenticelados, glabros; coléteres presentes na região nodal. Folhas opostas, iguais entre si; pecíolo 5-7 mm compr., glabro; lâmina foliar $9,8-10,5 \times 3,8-4,7 \mathrm{~cm}$, elíptica a ovada, ápice agudo a curto caudado, margem inteira, base aguda, subcoriácea, glabra, domáceas glabras em criptas na face abaxial, coléteres 2 na base da nervura central. Inflorescência terminal, tirsiforme, multiflora; pedúnculo $8,5-10 \mathrm{~mm}$ compr.; brácteas escamiformes, inconspícuas; botões florais cuneiformes, ca. $1 \mathrm{~mm}$ compr. . Flores brancas; pedicelo 1-2 mm compr., glabro; sépalas ca. $1 \mathrm{~mm}$ compr., iguais entre si, eretas, ovadas, glabras, coléteres presentes; corola sub-rotácea; lobos ca $3 \times 1,5 \mathrm{~mm}$, ovados; tubo ca. $1 \mathrm{~mm}$ compr., curto e obcônico, internamente piloso; estames parcialmente exsertos, inseridos próximo a 

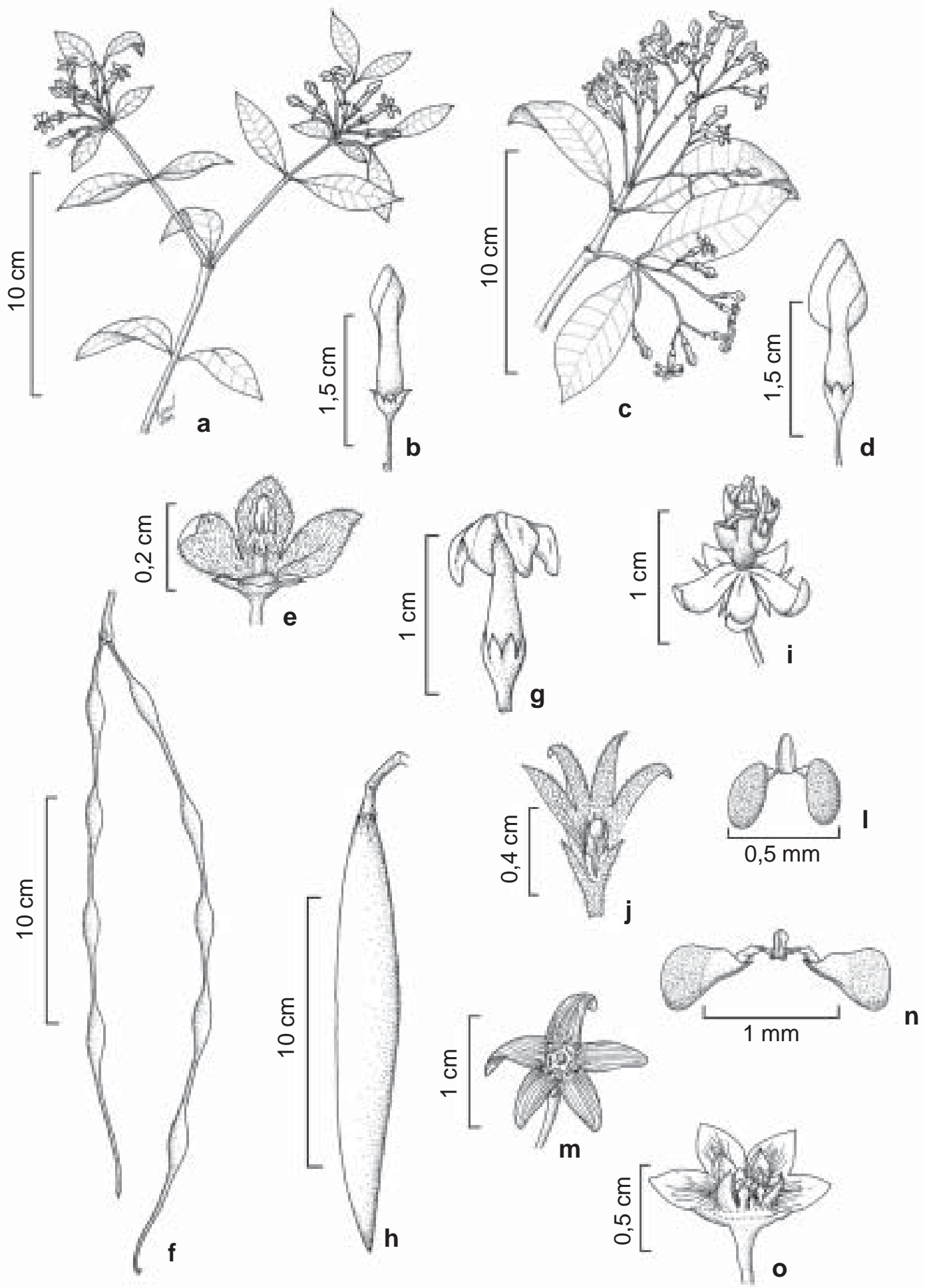

Figura 2 - a-b. Tabernaemontana hystrix - a. hábito; b. detalhe do botão floral. c-d. T. laeta - c. ramo com inflorescência; d. botão floral. e-f. Forsteronia refracta - e. flor, com duas lacíneas removidas; f. fruto. g-h. Secondatia densiflora - g. flor; h. fruto. i. Asclepias curassavica - i. flor. j-1. Ditassa tomentosa - j. flor com pétala removida; 1. polinário. m-n. Matelea capillacea - m. flor; $\mathrm{n}$. polinário. o. Macroditassa lagoensis var. cucullata - o. flor com pétala removida. (a-bCastro 744; cd Meireles s.n. (CESJ 31441); e-f Castro 145; g-h Castro 421; i Castro 471; j-1 Forzza 2178; m-n Lopes 30; o Castro 421). 
fauce, no nível da clavúncula; filetes parcialmente livres, com apêndice caloso; anteras ca. $1 \mathrm{~mm}$ compr., oblongas. Ovário ovóide, piloso; disco nectarífero 5-lobado; estilete ca. $1 \mathrm{~mm}$ compr., cilíndrico alargado na base; clavúncula oblonga, com 5 projeções e apêndice apical bífido. Folículos moniliformes, segmentados, castanhos, 15-20 cm compr. glabros; sementes $2-3 \mathrm{~cm}$ compr., subcilíndricas, coma alaranjada.

Material examinado: II.2001, fr., R. Castro \& P. Fiaschi 145 (CESJ).

Material adicional examinado: BRASIL. MINAS GERAIS: Coronel Pacheco, X.1970, fl., Hernizer 408 (RB); RIO DE JANEIRO: Vale do BonsucessoContorno, Rio-Petrópolis, XI.1970, fl., L. Krieger s.n. (CESJ 9615);

Forsteronia refracta é uma espécie heliófila que possui folículos moniliformes castanhos e sementes com coma alaranjada. Além disso, as domáceas nesta espécie são em forma de criptas glabras e os filetes apresentam apêndices. Ocorre amplamente na América do Sul e no Brasil, onde se estende pelas Regiões Centro-Oeste, Sudeste até Sul. Na RBRG, é encontrada na orla da mata ou em clareiras.

\section{Secondatia densiflora A.DC., Prodr. 8:} 445. 1844.

Fig. $2 \mathrm{~g}-\mathrm{h}$

Liana, ramos rugosos, avermelhados, lenticelados, glabros; coléteres ausentes na região nodal. Folhas opostas, iguais entre si; pecíolo 8-12 mm compr., canaliculado, glabro; lâmina foliar 6,6-7,6 × 2,4-3,3 cm, obovada, oblongo-elíptica a lanceolada, ápice acuminado, margem inteira, base cuneada, cartácea, glabra, com a face abaxial opaca e adaxial brilhante. Inflorescência terminal, raramente axilar, cimosa, multiflora; pedúnculo 3-4,5 cm compr., brácteas escamiformes, inconspícuas; botões florais de ápice elipsóide menor que o tubo. Flores brancas a creme; pedicelo 3-7 mm compr., glabro; sépalas ca. $2 \times 1 \mathrm{~mm}$ iguais entre si, eretas, ovadas, glabras, coléteres presentes; corola hipocrateriforme; lobos 5-3 $\times$ ca. $1,3 \mathrm{~mm}$, obliquamente obovados; tubo ca. $7 \mathrm{~mm}$ compr., estreito alargado na base, internamente piloso; estames inclusos, inseridos próximo a base do tubo, abaixo da clavúncula; anteras 3-4 mm, linear-lanceoladas. Ovário ovóide, glabro; disco nectarífero 5-lobado; estilete ca. 1,5 mm, cilíndrico; clavúncula cilíndrica de ápice cônico de mesmo tamanho do estilete. Folículos fusiformes, castanhos $13,5-16 \times 1,6-1,8 \mathrm{~cm}$, glabros; sementes $2-3$ cm oblongo-elípticas com coma alvo.

Material examinado: V.2001, fr., R. Castro et al. 420 (CESJ).

Material adicional examinado: BRASIL. MINAS GERAIS: Januária, IX. 2001, fl, fr., M. Bovini et al. 2327 (RB).

Secondatia densiflora tem ramos mais robustos que as demais lianas da reserva e um folículo lenhoso. Apresenta ampla distribuição por toda a América do Sul, alcançando até o sudeste do Paraguai. No Brasil, tem sua distribuição na região amazônica e principalmente no cerrado do Planalto Central do Brasil. Na RBRG, foi encontrada no interior de mata em locais bem iluminados.

\section{Subfamília Asclepiadoideae}

Folhas opostas. Corola com prefloração dextrorsa; anteras fortemente adnatas à clavúncula (ginostégio); pólen agrupado em polínias, presos a um translador, formando polinários.

9. Asclepias curassavica L., Sp. Pl. 1: 215. 1753.

Fig. 2 i

Erva, ramos glabros. Folhas opostas, pecíolo $0,8-1 \mathrm{~cm}$ compr., glabro; lâmina foliar $5,5-10 \times 1,7-2 \mathrm{~cm}$, lanceolada, ápice acuminado, margem inteira, base atenuada, glabra, cartácea; coléteres presentes na base da lâmina foliar. Inflorescência subaxilar, umbeliforme, 8-12 flores; pedúnculo 3,5-4 cm compr., tomentoso; pedicelo 6-13 mm compr., pubescente; sépalas reflexas, 3,2-3,5 ×0,7$0,8 \mathrm{~mm}$, linear lanceoladas, tomentosas; corola vermelha, rotácea, lobos 4-6 × 2,6-3,1 mm, oval-lanceolados, margem inteira, glabros em ambas as faces, reflexos. Corona simples, segmentos cuculados, providos de um cornículo adaxial inflexo. Ginostégio estipitado, ápice da 
clavúncula capitado a subplano; dorso das anteras retangular, apêndices membranáceos fletidos, asas mais longas que o dorso; retináculo sagitado, caudículas descendentes, polínias pendentes, claviformes, achatadas lateralmente. Fruto não observado.

Material examinado: VI.2001, fl., R. Castro et al. 471 (CESJ).

Asclepias curassavica é subespontânea e facilmente reconhecível por sua corola vermelha e corona amarela. Ocorre amplamente no Brasil. Na RBRG, é encontrada em clareiras ou bordas de matas.

10. Ditassa tomentosa (Decne.) Fontella, Bol. Mus. Bot. Munic. 39: 1. $1979 . \quad$ Fig. 2 j-1

Trepadeira, ramos volúveis, tomentosos. Folhas opostas, pecíolo ca. $5 \mathrm{~mm}$ compr., tomentoso, lâmina foliar 2-5×0,5-1,4 cm, elíptica a levemente obovada, ápice mucronado, margem revoluta, base cuneada, tomentosa, membranácea a cartácea; coléteres presentes na base da lâmina foliar. Inflorescência subaxilar, umbeliforme, 4-9 flores; pedúnculo 1,5-2,3 mm compr. tomentoso; pedicelo 1,32,2 mm compr., tomentoso; sépalas eretas, ca. $2 \mathrm{~mm}$ compr., ovais a lanceoladas, hirsutas; corola alva, campanulada, lobos ca. $5 \times 1,3 \mathrm{~mm}$, lanceolados, margem revoluta, glabros externamente, internamente pubérulos, eretos. Corona dupla, segmentos externos ovaltriangulares, mais baixos que o ginostégio, segmentos internos reduzidos a pequenas projeções inseridas abaixo do dorso das anteras. Ginostégio séssil, ápice da clavúncula capitado; dorso das anteras subcônico, apêndices membranáceos eretos, asas mais longas que o dorso; retináculo oblongo, caudículas horizontais, polínias pendentes, ovóides. Fruto não observado. Material examinado: IV.2002, fl., R.C. Forzza et al. 2178 (CESJ).

Ditassa tomentosa é típica por seu indumento nas folhas e lobos da corola sempre eretos (Konno 2005). Ocorre no Brasil, nos estados de Minas Gerais, Rio de Janeiro, São Paulo e Paraná, em áreas de cerrado, florestas estacionais e floresta atlântica. Na RBRG, é encontrada no interior e orla da mata.
11. Macroditassa lagoensis var. cucullata (E. Fourn.) Fontella \& M.V. Ferreira, Bradea 8 (18): 102. 1998.

Fig. 20

Trepadeira, ramos volúveis, glabros. Folhas opostas, pecíolo 1,5-2,2 cm compr., glabro, lâmina foliar 9,2-11,4 × 4-4,5 cm, elíptica a levemente obovada, ápice cuspidado a curto caudado, margem inteira, base cuneada, glabra, membranácea a cartácea, coléteres presentes na base da lâmina foliar. Inflorescência umbeliforme, axilar, oposta, 45 flores; pedúnculo 1,5-2,3 cm compr., glabro; pedicelo 1-1,2 cm compr., glabro; sépalas eretas, ca. $2 \times 1 \mathrm{~mm}$ compr., ovais triangulares, glabras; corola roxa em botão e alva quando em antese, rotácea, lobos ca. $5 \times 2,5 \mathrm{~mm}$, ovais triangulares, margem inteira, papilosos, barbelados na porção mediana basal, suberetos. Corona dupla, segmentos externos ovallanceolados, cuculados na base, mais altos que o ginostégio e internos tão longos quanto o ginostégio. Ginostégio séssil, ápice da clavúncula mamilado; dorso das anteras quadrado, apêndices membranáceos eretos, asas tão longas quanto o dorso; retináculo oblongo, caudículas horizontais, polínias pendentes, oblongas. Fruto não observado.

Material examinado: V.2001, fl., R. Castro et. al. 421 (CESJ).

Macroditassa lagoensis var. cucullata possui flores com lobos barbelados e flores de coloração alva. O gênero tem distribuição exclusiva na América do Sul, com espécies encontradas principalmente nas matas ciliares dos estados de MG, RJ e SP, entre 400 e 1150 $\mathrm{m}$ de altitude. M. lagoensis var. cucullata está representada no estado de Minas Gerais, até o presente trabalho, apenas por coletas de Carangola (Fontella-Pereira \& Ferreira 2005). $\mathrm{Na}$ RBRG, é encontrada no interior da mata.

12. Matelea capillacea (E. Fourn.) Fontella \& E.A. Schwarz, Bol. Mus. Bot. Munic. 46: 6. 1981.

Fig. 2 m-n

Trepadeira, ramos volúveis, glabros. Folhas opostas, pecíolo 1-2 cm compr., glabro; lâmina foliar 8-17×2,5-5 cm, lanceolada, ápice 
agudo, margem inteira, base cuneada, glabra, membranácea a subcartácea; coléteres presentes na base da lâmina foliar. Inflorescência umbeliforme, axilar, 5-7 flores; pedúnculo 5-10 cm compr., glabro; pedicelo 3-4 cm compr., glabro; sépalas eretas, ca. 2 mm compr., lanceoladas, glabras; corola verde, rotácea, lobos 8-9 $8 \times 3,2-3,5 \mathrm{~mm}$, lanceolados, margem inteira, providos de calosidades verrucoso-tomentosas na fauce e entre os lobos, glabros em ambas as faces, patentes. Corona com segmentos ginostegiais totalmente unidos entre si, formando um anel carnoso, bicornados no ápice. Ginostégio estipitado, ápice da clavúncula depresso; dorso das anteras obtrapeziforme, asas mais longas que o dorso; retináculo sagitado, caudículas horizontais, articuladas, polínias horizontais, dolabriformes. Folículo fusiforme, 5-costado; sementes ovadas com ápice denteado.

Material examinado: X.2001, fl., A. Lopes \& V. Scalon 30 (CESJ); XI.2001, fl., G. Augustin et al. s.n. (CESJ 35080); I.2002, fr., R.Castro et al. 760 (CESJ); XI.2002, fl., M.O. Pivari et al. 170 (CESJ).

Matelea capillacea é característica por suas flores verdes de estrias e folhas cinéreas na face abaxial. No Brasil, tem sido coletada nos estados de Minas Gerais, Rio de Janeiro e Espírito Santo (Fontella-Pereira \& Schwarz 1981). Ocorre na RBRG no interior de mata e mata ciliar.

\section{Agradecimentos}

As autoras agradecem ao Herbário Leopoldo Krieger (CESJ) pela infra-estrutura cedida; a Rafaela C. Forzza pelo incentivo à execução desta monografia; a Ingrid Koch pelos imprescindíveis comentários taxonômicos; a Luiz Menini Neto pela confecção das ilustrações e aos revisores anônimos pelas valiosas sugestões.

\section{REFERÊNCIAS BIBLIOGRÁFICAS}

Almeida, V. R.; Temponi, L. G. \& Forzza, R. C. 2005. A família Araceae na Reserva Biológica da Represa do Grama, Descoberto, Minas Gerais, Brasil. Rodriguésia 56(88): 127-144.
Assis, L. C. S.; Forzza, R. C. \& Werff, H. van der. 2005. A família Lauraceae na Reserva Biológica da Represa do Grama, Descoberto, Minas Gerais, Brasil. Boletim de Botânica da Universidade de São Paulo 23(1): 113-139.

Braz, D. M., Carvalho-Okano, R. M. \& Kameyama, C. 2002. Acanthaceae da Reserva Florestal Mata do Paraíso, Viçosa, Minas Gerais. Revista Brasileira de Botânica 25(4): 495-504.

Drummond, G. M.; Martins, C. S.; Machado, A. B. M.; Baio, F. C. A. \& Antonini, Y. 2005. Biodiversidade em Minas Gerais: um atlas para sua conservação. $2^{\mathrm{a}}$ ed. Fundação Biodiversitas, Belo Horizonte, 222p.

Endress, M. E. \& Bruyns, P. V. 2000. A revised classification of the Apocynaceae s.1. The Botanical Review 66: 1-56.

Fallen, M. E. 1983. A taxonomic revision of Condylocarpon (Apocynaceae). Annals of the Missouri Botanical Garden 70: 149-169.

Fontella-Pereira \& Schwarz, E. A. 1981. Estudos em Asclepiadaceae XIII: novos sinônimos e novas combinações. Boletim do Museu Botânico Municipal, Curitiba, 46: 1-10.

Fontella-Pereira \& Ferreira, M. V. 2005. O gênero Macroditassa (Apocynaceae Asclepiadoideae) no Brasil. Bonplandia 14 (1-2): 7-34.

Giulietti, A. M.; Harley, R. M.; Queiroz, L. P.; Wanderley, M. G. L. \& Van den Berg, C. 2005. Biodiversity and Conservation of Plants in Brazil. Conservation Biology 19(3): 632-639.

Koch, I. \& Kinoshita, L. S. 1999. As Apocynaceae da região de Bauru, SP. Acta Botanica Brasilica 13(1): 61-86.

Koch, I. 2002. Estudos das espécies neotropicais do gênero Rauvolfia L. (Apocynaceae). Tese de Doutorado. Universidade Estadual de Campinas, Campinas.

Konno, T. U. P. 2005. Ditassa R.Br. no Brasil (Asclepiadoideae-Apocynaceae) Tese de 
Doutorado. Universidade de São Paulo, São Paulo.

Leeuwenberg, A. J. M. 1994. A revision of Tabernaemontana. II: The New World Species and Stemnadenia. Series of revisions of Apocynaceae: XXXVI. Royal Botanical Gardens, Kew, 450p.

Lobão, A. Q.; Forzza, R. C. \& Mello-Silva, R. 2006. Annonaceae da Reseva Biológica da Represa do Grama, Descoberto, Minas Gerais, Brasil, com uma nova espécie Unonopsis bauxitae. Rodriguésia 57(1): 137-147.

Lopes, W. P.; Paula, A.; Sevilha, A. C. \& Silva, A. F. 2002. Composição da flora arbórea de um trecho de floresta estacional no Jardim Botânico da Universidade Federal de Viçosa (face sudoeste), Viçosa, MG. Revista Árvore 26(3): 339-347.

Marangon, L. C.; Soares, J. J. \& Feliciano, A. L. P. 2003. Florística arbórea da Mata da Pedreira, município de Viçosa, Minas Gerais. Revista Árvore 27(2): 207-215.

Marcondes-Ferreira, W. 1988. Aspidosperma Mart. nom. cons. (Apocynaceae): revisão taxonômica. Tese de Doutorado. Universidade Estadual de Campinas.

Meira-Neto, J. A. A.; Souza, A. L.; Silva, A. F. \& Paula, A. 1997. Estrutura de uma floresta estacional semidecidual submontana em área diretamente afetada pela Usina Hidrelétrica de Pilar, Ponte Nova, Zona da Mata de Minas Gerais. Revista Árvore 21(3): 337-344.

Menini Neto, L.; Almeida V. R. \& Forzza, R. C. 2004. A família Orchidaceae na Reserva Biológica da Represa do Grama, Descoberto, Minas Gerais, Brasil. Rodriguésia 55(84): 137-156.

Oliveira-Filho, A. T.; Scolforo, J. R. \& Mello, J. M. 1994. Composição florística e estrutura comunitária de um remanescente de floresta semidecídua montana em Lavras (MG). Revista Brasileira de Botânica 17(2): 159-174.

Oliveira-Filho, A. T. 2006. Catálogo das árvores nativas de Minas Gerais: mapeamento e inventário da flora nativa e dos reflorestamentos de Minas Gerais. UFLF, Lavras, 423p.

Pereira, Z. V.; Carvalho-Okano, R. M. de \& Garcia, F. C. P. 2006. Rubiaceae Juss. da Reserva Florestal Mata do Paraíso, Viçosa, MG, Brasil. Acta Botanica Brasilica 20(1): 207-224.

Pivari, M. O. \& Forzza, R. C. 2004. A família Palmae na Reserva Biológica da Represa do Grama - Descoberto, Minas Gerais, Brasil. Rodriguésia 55(85): 115-124.

Plumel, M. M. 1991. Le genre Himatanthus (Apocynaceae). Révision taxonomique. Bradea 5: 1-118.

Projeto RADAMBRASIL. 1983. Levantamento de Recursos Naturais, Folha Goiânia (SE22). Departamento Nacional de Produção Mineral, Rio de Janeiro, 764p.

Ribas, R. F.; Meira-Neto, J. A. A.; Silva, A. F. \& Souza, A. L. 2003. Composição florística de dois trechos em diferentes etapas serais de uma floresta estacional semidecidual em Viçosa, Minas Gerais. Revista Árvore 27(6): 821-830.

Silva, N. R. S.; Martins, S. V.; Meira-Neto, J. A. A.; Souza, A. L. de. 2004. Composição florística e estrutura de uma floresta estacional semidecidual montana em Viçosa, MG. Revista Árvore 28(3): 397405.

Spina, A. P. 2004. Estudos taxonômicos, micromorfológico, e filogenético do gênero Himatanthus Willd. ex Schult (Apocynaceae: Rauvolfioidae-Plumerieae). Tese de Doutorado. Universidade Estadual de Campinas. 